\title{
DYNAMICS OF THE INTERRELATION BETWEEN INFLATION AND GLOBALIZATION IN CANADA AND THE USA
}

\author{
Aditya Bihani, Amogh Chaube, Darsh Kachhara, Mitali Mane, Radhika Mohta and Yash Jain
}

Third year, Bachelor's of Science in Economics, NMIMS, Mumbai

DOI: 10.46609/IJSSER.2020.v05i08.021 URL: https://doi.org/10.46609/IJSSER.2020.v05i08.021

\begin{abstract}
This research examines the impacts of changes in exchange rates on trade and capital flows between Canada and the United States of America. We seek to study the presence and degree of influence of several variables on exchange rates. Highlighting the degree of financial linkage between the two nations, we also test the relevance of the Covered Interest Rate Arbitrage Parity condition.

The Appendix of this research paper contains information on NAFTA, Global Financial Crisis, and analysis of Neo-Fisherism. Furthermore, a few regressions, if needed for explanation purposes are mentioned in the appendix. Due to word limitations, an element of our research testing Neo-Fisherism) which we did in the course of this Paper is also mentioned in the appendix.
\end{abstract}

Key Words: USA, Canada, CIAP, Inflation, Globalizatin

\section{Introduction}

Globalisation and inflation have had effects in every sector of the economy. Due to globalisation, the importance of exchange rate has also heightened. Globalisation encourages cross-border transactions and Exchange rates are an important factor which affects cross-border economic transactions.

Exchange rates have important implications on trade and capital flows of the nation. For example, if there is a depreciation in the currency, it makes capital investments for foreign investors cheaper and vice-versa. But, within the country, depreciation of a currency leads to exchange-rate volatility risk further leading to several economic risks if firms engage in international trade. 


\section{International Journal of Social Science and Economic Research}

ISSN: $2455-8834$

Volume:05, Issue:08 "August 2020"

The first objective of the paper is to determine the factors which influence Exchange rates. The second objective is to analyse the relationship and impact of exchange rate on trade and capital flows between Canada and United States of America. The analysis is based on the data from 1991-2017, which is further divided into three periods.

The two nations were specifically chosen because both are free market proponents, technologically advanced and have flexible exchange rate. They have a massive trade and financial linkage for quite some time. This makes it easier to study a cause and effect relationship between different domestic macroeconomic variables and their impact on other countries via exchange rate.

Furthermore, since we are attempting to study the factors influencing exchange rates between the two nations as well, both nations have to be significantly linked with the other to have an observable and explainable impact of a change in domestic variables which result in a change in exchanges rates, trade, capital flows and so on.

The two nations have seen two common major milestones - one being NAFTA, which is a positive for trade and capital flows, and the second is the Global Financial Crisis which posed as a negative to trade and capital flows. Lastly, most markets between the two economies are closely linked (cyclicallytoo) which is why explaining trends of data of one country with respect to the other would be more sensible.

\section{Literature Review:}

\subsection{Impact of Exchange on Trade:}

Paul De Grauwe (1998), "Exchange Rate Variability and Slowdown of Growth on International Trade". The examines effects of exchange rate on trade.

Two models, Simple production and consumption model under risk and the mechanism was called political economy effect of exchange rate variability, were used to examine the behavior of international trade under exchange rate risk. For analysis export data, growth rate and index of exchange rate market was used which taken from OECD (statistics on foreign trade) and IMF (International Financial Statistics).

Variability caused to the floating exchange system is supposed to create uncertainty in the global market which should result in a decline in trade, however, the theory on production and consumption under risk predicted an ambiguous effect on trade.

Another model called political economy effect was made to study exchange rate variability. The model says that political and economic factors have an impact on trade and not exchange rates per say; any change on 'e' rates are due to such factors themselves. 
International Journal of Social Science and Economic Research

ISSN: 2455-8834

Volume:05, Issue:08 "August 2020"

Baum, Caglayan (2010) showed similar findings using the M-GARCH BEKK Model and EngleGranger Regression, for a set of countries including Canada and USA.

\subsection{Factors influencing Exchange rates:}

A paper by the Reserve bank of Canada shows how the world prices of the commodity, economic performance, productivity record, relative interest rates and short-term capital flows are directly related to exchange rate of the country that is exporting commodities to the other country.

It also states how Factors such as inflation rates and domestic political turmoil are something that are inversely related to exchange rate of the country exporting the commodities. The Major reasons amongst all other determinants that makes exchange rate fluctuate in any country are: Purchasing Power Parity and Commodity Prices.

Similarly, in his paper, "Determinants of the Canada-US Exchange Rate", Francis Fong, highlights how interest rate differentials, inflation and commodity price differentials, current account positions, relative political and economic states and productivity have significant effect on exchange rates. A report published by Jeannine Bailliu, and Michael R. King of the Bank of Canada highlight the same. The way these variables affect 'e' rates are highlighted and mentioned in the analysis section.

\subsection{Validity of the Covered Interest Rate Parity:}

'Nonlinear Dynamics and Covered Interest Rate Parity' - (Nathan S. Balke\& Mark E. Wohar, 1997), examines the number of observations beyond the transaction cost band and further also studies the persistence of such observations.

The model used is the Threshold Autoregression ARCH to capture variable volatility nature of CIP deviations and study the change in behavior of it within and beyond the neutral zone and persistence of deviations by employing non-linear impulse response analysis.

The data is obtained for a period of about 20 years (1974-93). Data for ask and bid prices of forward rates (one-month term), spot rates in British pounds and interest rates is obtained from Data Resources Incorporated (DRI).

It is found that there are a number of observations which exceed the neutral zone which implies that the CIP doesn't hold so the construction of forward rates is into question. However, large systematic profits cannot be made as empirical evidence suggests it's rare. Also, Profit-making opportunities are only for a short period. 
International Journal of Social Science and Economic Research

ISSN: 2455-8834

Volume:05, Issue:08 "August 2020"

Frenkel and Levich $(1975,1977)$, define a "neutral zone as the area which surrounds the CIP condition above and below, within which observed deviations from CIP can occur without yielding any profit after netting out transactions costs." They estimate these costs using data on triangular arbitrage and conclude that CIAP hold.

\subsection{Trade and Finance between US and Canada:}

"Rita Yi Man Li and Jennifer Li" (2013), study the impact of US subprime mortgage on the housing market in Canada given the close relationship between them. Reviewing the official statistics data in the US and Canada, this paper firstly sketches the macro economy and housing market of Canada and the US before and after subprime financial crisis.

\section{Data:}

Major data sources are World Bank Datasets, OECD Datasets and CEIC Datasets.

Mostly nominal exchange rates are used for our analysis since most variables under analysis are nominal.As a measure of yearly nominal interest rates in the economy, we make use of an average of short term deposit rates for the given year; we use short term interest rates because, as defined by the database "it is an average of interbank rates, policy rates and short term government security rates ( where short term is $3-5$ years )"; thus short term interest rates reflect better short term fluctuations.

Data used apart from these, have been defined in usage and reason wherever required. Trade data is collected form the WITS website.

\section{Methodology}

Our analysis in the paper is broadly divided into three components.

First component is Factors influencing exchange rates. We make use of regression to check how relative inflations and relative interest rates influence the nominal exchange rates. Taking this further, we check the impact of two more variables, namely EDBI and relative factor productivity. Finally, a multi-variate regression is used with all the variables.

We then shift impact of exchange rate on trade - which using regression analysis provides insignificant results. Thus, we break up the times period into multiples components and analyze each in isolation. 
Finally, we study exchange rates and capital flows - we restrict capital flow to financial flows. Again, since regression results prove insignificant, we make use of descriptive analysis. In addition to this we test the CIAP principle.

All regressions are done using indexed values of the variables; by indexing we narrow each variable between 0 and 1 . This is done for ease of comparison, especially in multi-variate regression. Indexing, does not in any way change correlationand regression coefficients.

\section{Analysis}

\subsection{Factors affecting Exchange Rates between Canada and the USA:}

\subsubsection{Relative domestic inflation:}

Using the idea of relative PPP, we understand that to maintain purchasing power parity higher the domestic inflation in a country relative to another, the weaker its currency would get in the next time period. The equation as given below indicates the same:

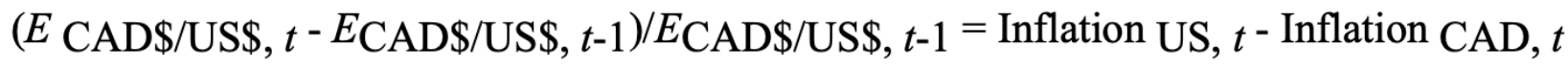

\section{E CAD\$/US\$ Nominal Exchange rate of Canada in terms of Dollar}

The equation implies a positive relation between relative inflation (Infla CAD / Infla US ) and Exchange Rate $\mathbf{E}_{\mathbf{C A D}}$ /US\$.

To check the extent of the same we run a regression between indexed values of relative inflation ('id.i' ) and exchange rates ( 'id.e' ) . (time - 1960-2018):

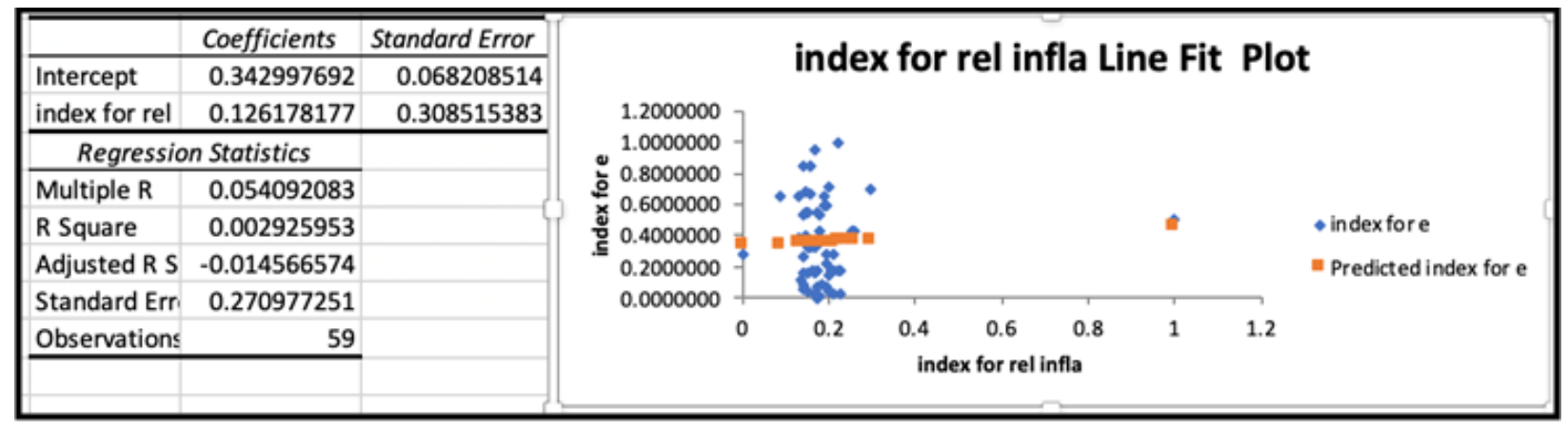


As we can see above, the coefficient of 0.126178177 indicates that a unit change in 'id.i' leads to a 0.126178177 change in 'id.e'. Furthermore, the incredibly low value of R Square indicates the poor dependency of exchange rates on relative inflation rates.

\subsubsection{Relative interest Rates:}

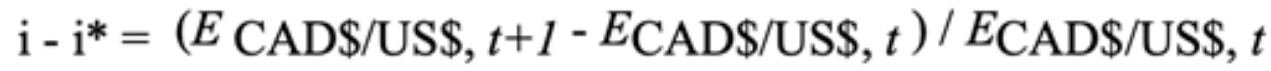

$$
\begin{aligned}
& \text {; where } i=\text { Canada interest rates } \\
& i^{*}=\text { USA Interest Rates } \\
& \text { Or, differently put : }
\end{aligned}
$$

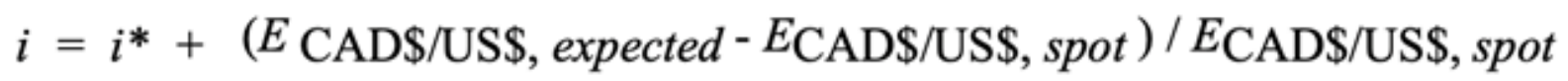

$$
\begin{aligned}
& \mathrm{i}-\mathrm{i}^{*}=\left(E_{\mathrm{CAD}} \mathbf{\mathrm { US }} \$, t+1-E_{\mathrm{CAD}} \mathbf{\mathrm { US }} \$, t\right) / E_{\mathrm{CAD}} / \mathrm{US} \$, t \\
& \text {; where } i=\text { Canada interest rates } \\
& i^{*}=\text { USA Interest Rates } \\
& \text { Or, differently put : }
\end{aligned}
$$

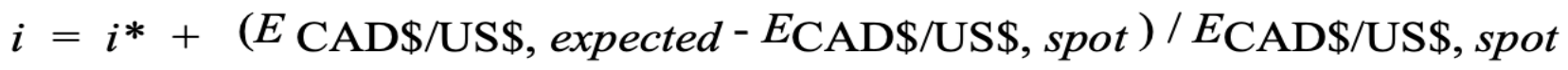

The relation between nominal interest rates (' $i$ ') and ' $\mathrm{e}$ ' rates is one that can be explained by the equation used for CIAP:

According to the relation above:

'i' rises - capital inflow - currency appreciates $-E_{\mathrm{CAD}} \mathbf{\mathrm { US }} \$, t$ falls - foreign currency at a premium.

Thus, existence of an inverse ration between 'i' and 'e' rates. For comparison between Canada and USA we compare relative interest rates ( $\mathrm{i} C A D / i^{*} \mathrm{US}$ ).

We find relative ' $i$ ' rates, and then regress the indexed values of the same with indexed 'e'. (Time period - 1965 - 2017) 
International Journal of Social Science and Economic Research

ISSN: 2455-8834

Volume:05, Issue:08 "August 2020"

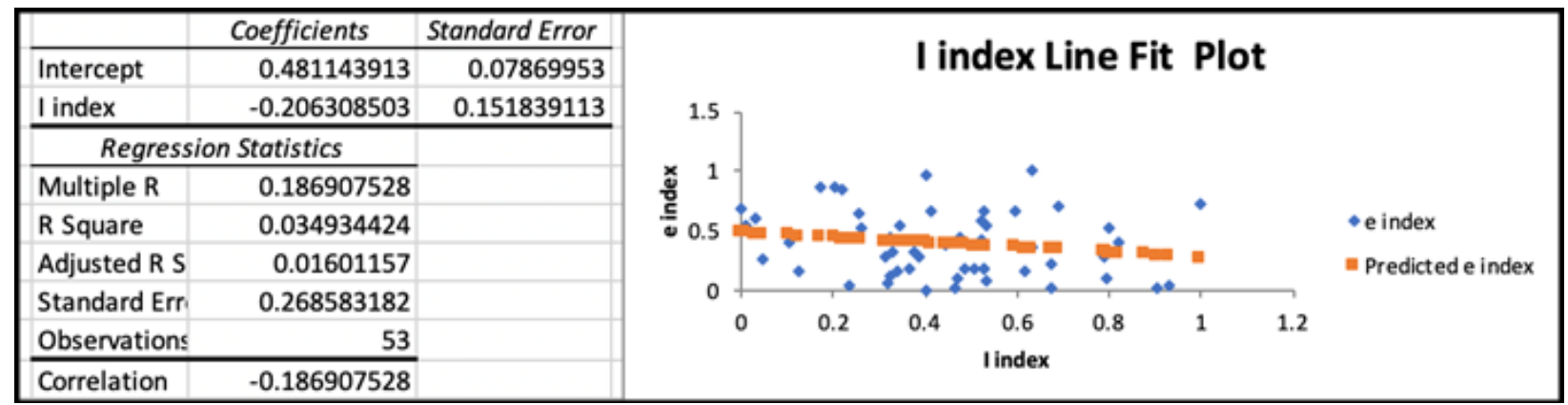

The negative correlation, does satisfy the negative relation between the two, however the low value of 'R Square' in indicative of the low explainable dependence between the two.

\subsubsection{A Multivariate Regression Model:}

Two more important variables we come across in our literature review were relative factor productivity and political/economic image/state of the economy (Ease of doing Business used as a proxy). Regression in isolation for the same has been done in the appendix. Here we combine indexes of the four variables for a multivariate regression.

We used indexed values for all variables, for the time period 2006-2017 (to accommodate all variables given data availability limitations). The results are below: 


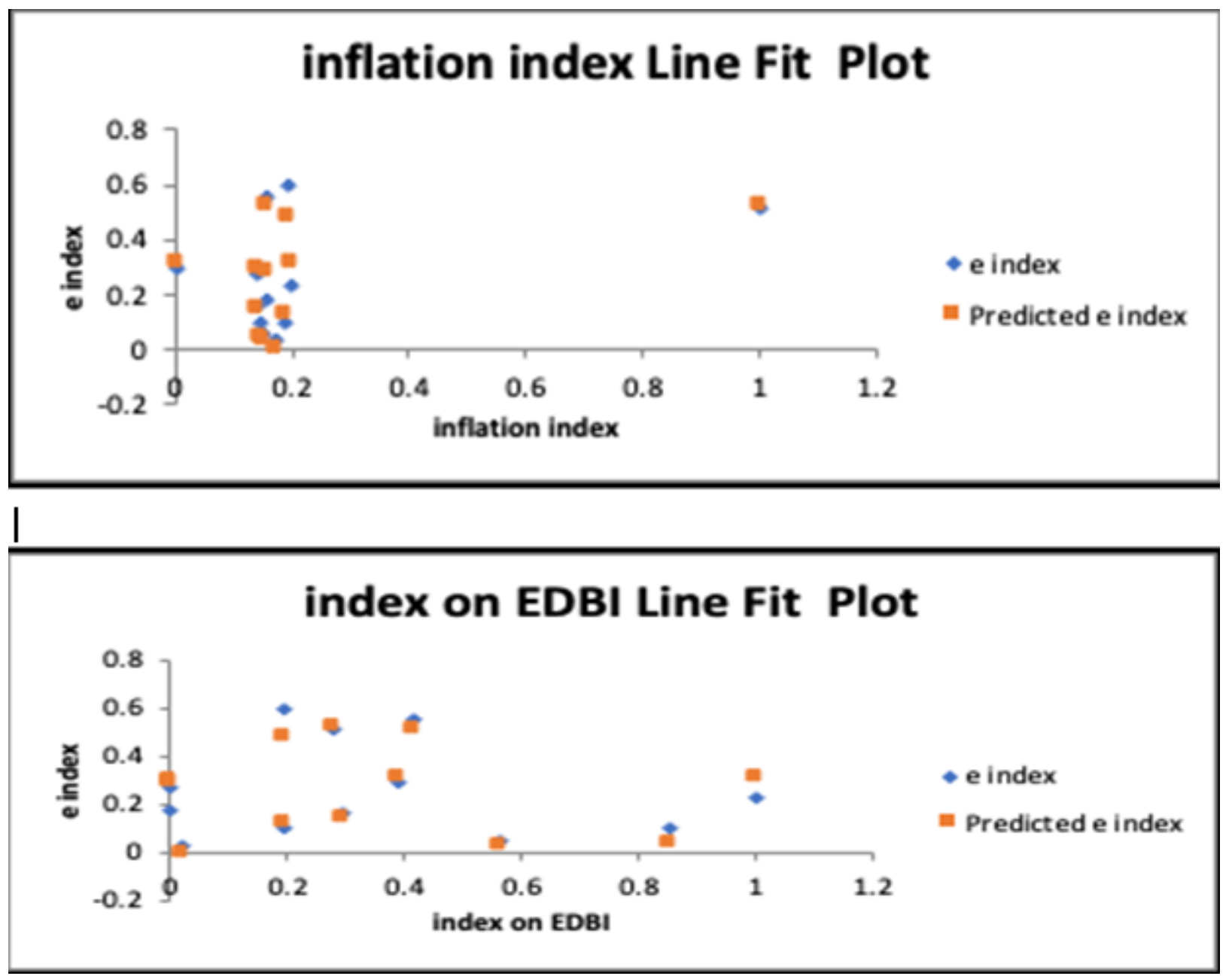




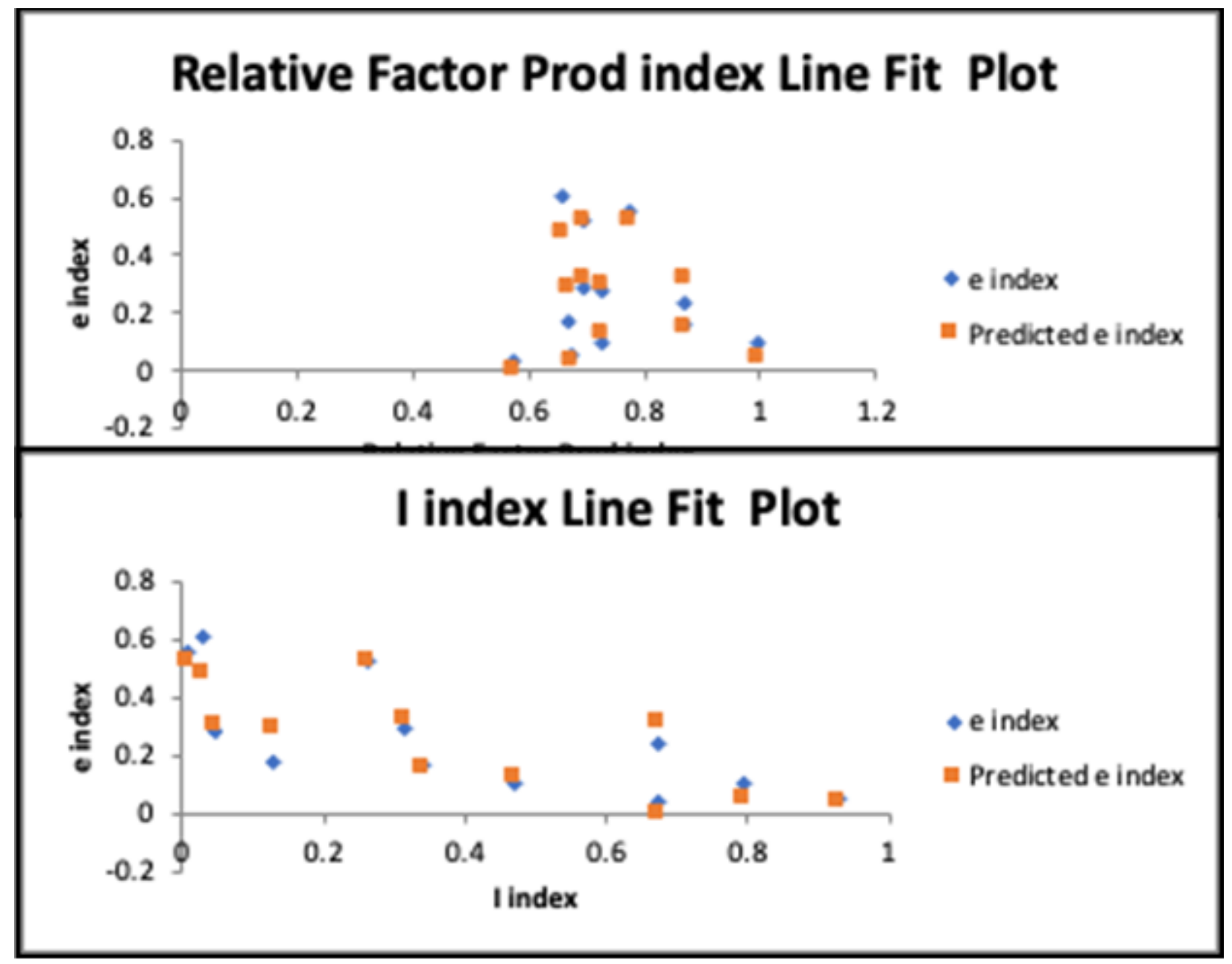


International Journal of Social Science and Economic Research

ISSN: 2455-8834

Volume:05, Issue:08 "August 2020"

\begin{tabular}{|l|r|r|}
\hline & \multicolumn{1}{|c|}{ Coefficients } & \multicolumn{1}{|c|}{ Standard Error } \\
\hline Intercept & 0.840701529 & 0.213829046 \\
\hline index on EDBI & 0.542072368 & 0.1310134 \\
Relative Factor Prod index & -0.743487124 & 0.305635487 \\
I index & -0.692099534 & 0.095860541 \\
\hline inflation index & 0.230106647 & 0.095209625 \\
\hline \multicolumn{2}{|c|}{ Regression Statistics } \\
\hline Multiple R & 0.949466177 & \\
\hline R Square & 0.901486021 & \\
\hline Adjusted R Square & 0.845192319 & \\
\hline Standard Error & 0.078025603 & \\
\hline Observations & 12 & \\
\hline
\end{tabular}

As we see above, R-Square is 0.90148 ; thus $90.148 \%$ variability of index of 'e' rates can be explained by combined changes of the indexes of the four variables analyzed in this paper.

Furthermore, from the regression coefficients we can also deduce which variables have greater effects on ' $e$ ' rates. By simply finding the ratio of each variable's regression coefficient to the sum of all regression coefficients we get the relative weightage of each.

(we take positive values of each coefficient, furthermore since we are using indexed values, we can use this method to check weightage.However, as assumption made is that the volatility of each variable is equal in terms of relative movement from the mean). The relative weights are given below:

\begin{tabular}{|l|r|}
\hline Indexed Variables & weights \\
\hline index on EDBI & $25 \%$ \\
\hline Relative Factor Prod index & $34 \%$ \\
\hline I index & $31 \%$ \\
\hline inflation index & $10 \%$ \\
\hline
\end{tabular}

A limitation is that our time period for the multivariate analysis is small. In addition, since our analysis is done between Canada and the USA in particular, there are likely to be distortions throughout, given the vehicle currency nature of the US \$. However, considering the fact the Dollar has for quite some time remained a vehicle currency it is possible that its overvalued 
nature could have remained relatively constant over the time periods we have considered, as a result not having much of a distorting effect.

Furthermore, as is evident from the weights above, relative factor productivity can have a surprisingly great effect on the ' $\mathrm{e}$ ' rates. One reason for the same could be that factor productivity moulds expectations which can often turn into reality; expectations tend to fulfil themselves.

It is also evident that ' $\mathrm{e}$ ' rates depend greatly on investor expectation and image of Canada; in addition to which relative interest rates act as obvious motivations. However, relative inflation which can be more of a domestic phenomenon, seem to have less causal effect on 'e' rates.

\subsection{Exchange Rate Fluctuations and its impact on Trade and Capital Flows}

\subsubsection{Impact on Trade}

\section{Canadian Exports and nominal 'e' rate fluctuations:}

The general trend, considering the causal link to be from ' $\mathrm{e}$ ' rates to trade is:

a rise in ' $\mathrm{e}$ ' (depreciation) - increase in exports (since, exports of the domestic country would become relatively cheaper)

However, if we consider the causal relation to be the other way, then an increase in exports increases demand for a nation's currency- reducing 'e' (orappreciation).

The trend for exports and imports of Canada and ' $\mathrm{e}$ ' rates are shown in the graphs below: 
International Journal of Social Science and Economic Research

ISSN: 2455-8834

Volume:05, Issue:08 "August 2020"

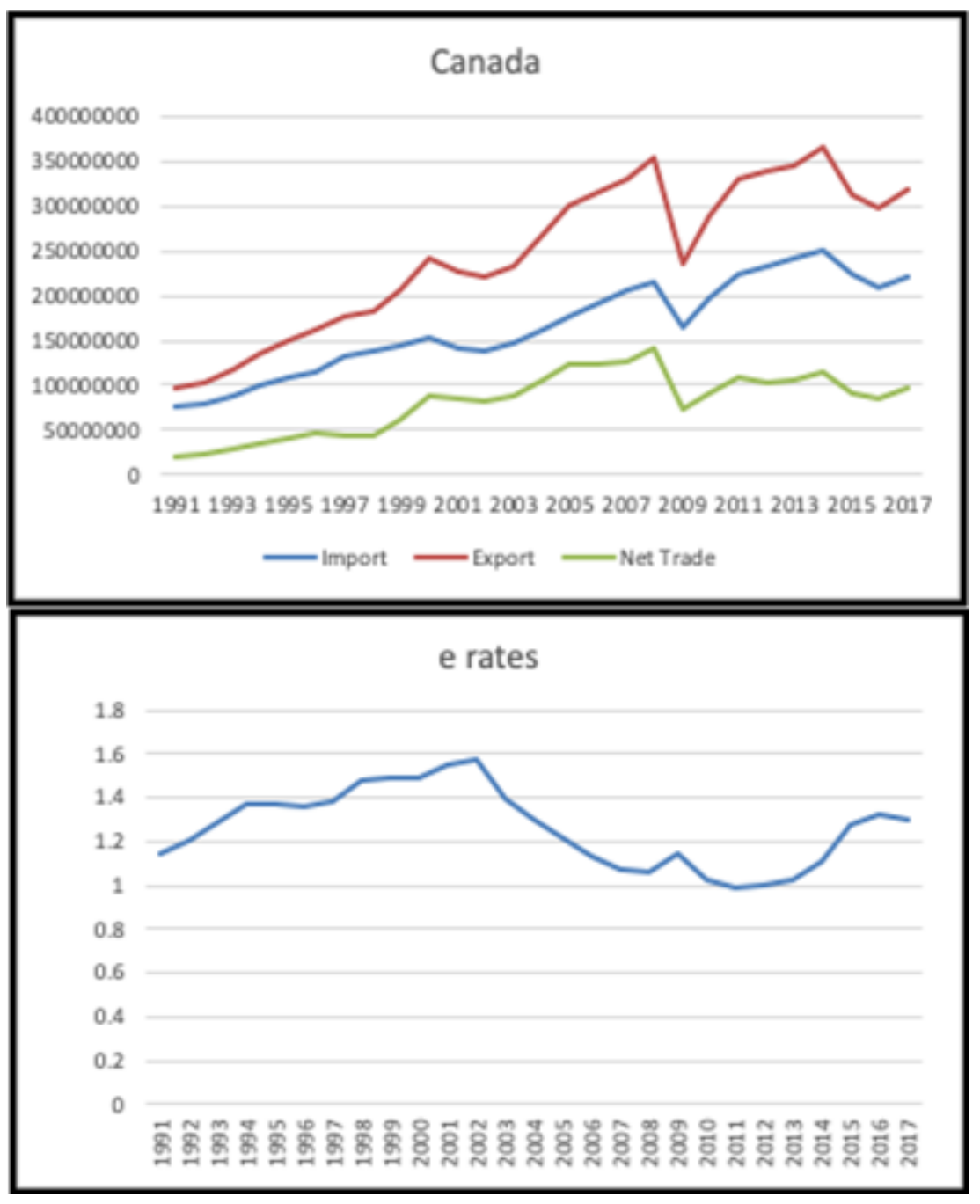

As is evident above, the 'e' rates can be divided into three distinct time periods (1991-2000, 2001-2008, 2009-2017) to present a piecemeal analysis based on the broader trend of the same. Furthermore, this division of time is done because a simple correlation over the entire time periods provides largely insignificant results which are ambiguous.

The correlation values for the time periods are as follows:

\begin{tabular}{|c|c|c|c|}
\hline \multicolumn{2}{|c|}{ Correlation table: } & Imports & Exports \\
\hline $1991-2000$ & $\mathrm{e}^{\prime}$ rates & 0.9388448 & 0.91253404 \\
\hline $2001-2008$ & $\mathrm{e}^{\prime}$ rates & -0.9626933 & -0.9709104 \\
\hline 2009-2017 & $e^{\prime}$ rates & -0.16414 & -0.2749962 \\
\hline
\end{tabular}




\section{International Journal of Social Science and Economic Research}

ISSN: $2455-8834$

Volume:05, Issue:08 "August 2020"

As is evident from above:

For the 1st time period a strong positive correlation between ' $e$ ' and, imports and exports suggest that the causal link is from 'e' rates to exports and from imports to 'e' rates.

In other words, rising 'e' paved the way for rising exports, however since imports were also rising, 'e' rates kept rising. This can be explained by high domestic growth, which finds its way through increased imports consumption, along with a good export growth to meet the income need to satisfy such import consumption. This a beneficial cycle.

Furthermore, we need to keep in mind the importance of NAFTA in this context. The trend of a strongly correlated movement of imports and exports throughout, could be indicative of the conditions of the trade agreement as well. After 1994, Canada was much more open to US imports and also gained greater access to US markets, thus both imports and exports grew simultaneously. At the same time, the idea of retaliation in such agreements can also have a tendency for exports and imports to exhibit the similar trends.

For the second time period, a strong negative correlation suggest that the causal is opposite. In other words, falling ' $\mathrm{e}$ ' paved the way for rising imports, however since exports were also rising, 'e' rates kept falling.

Trade between the two saw a slight dip post 2000, which was primarily due to the stricter regulations imposed by the US in light of the 9/11 attacks.

Finally, for the last time period, the correlation is a slight negative, and is insignificant. This period - global financial crisis - saw a sharp fall in 'e' as the US \$ suffered the wrath of low confidence. However, with time, gaining its safe haven currency reputation, 'e' started rising. Trade witnessed a sharp decline straight after the financial crisis, given low incomes, low demands and hence lower consumption. However, as the economies recovered (keep in mind that Canada, being so closely integrated with the US also suffered during the GFC) trade numbers picked up again.

It is also important to take note of the fact that Canada has throughout this time period seen current account surpluses, which has also seen a long run increasing trend, which can be interpreted as advantageous to Canada.

\section{J - Curve Effect:}




\section{International Journal of Social Science and Economic Research}

ISSN: 2455-8834

Volume:05, Issue:08 "August 2020"

Yet another explanation to the correlations in for the time periods which go against the " $\mathrm{e}$ ' rates to trade" causal link, is that of the J-Curve. With a depreciating currency, even though imports should fall, their often-inelastic nature makes them go against this trend. The logic remains same for the other situation.

Furthermore, even if we try and related it to real exchange rates, the trend of exports and imports shows congruence. Real ' $\mathrm{e}$ ' rates as is evident move in an opposite trend to their nominal counterparts. Nonetheless, explaining trade will still have to be done time periods, and the causal explanations for this analysis become opposite to that explained for nominal 'e' rates:

In conclusion, our findings move in tandem with the literature we reviewed, wherein trade was impacted more by the "political economy" factors and not quite explained by exchange rates.

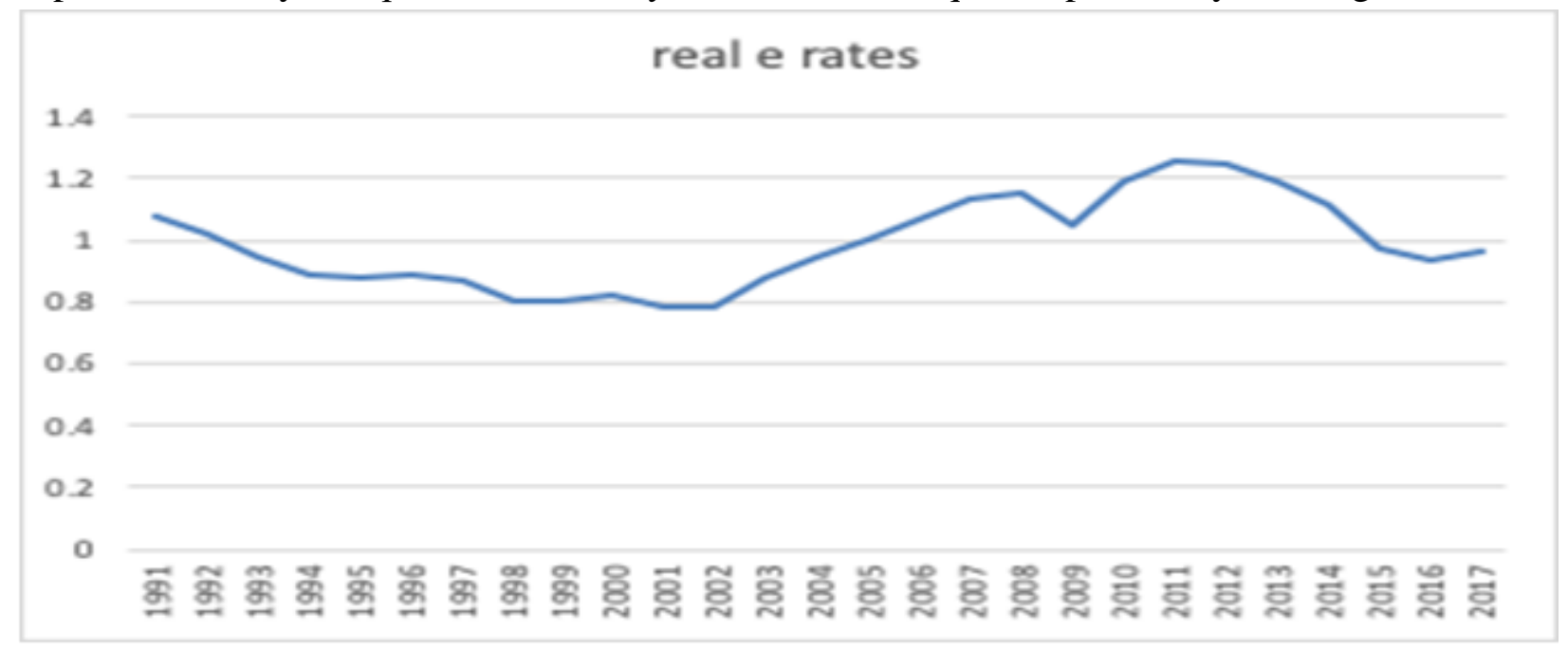

\subsubsection{Impact on Financial/Capital Flows:}

Since we are discussing capital flows and they linkage with 'e' rates, we shall consider only Financial flows as part of our study. This is so because capital flows in the form of FDI, tends to have less connection with 'e' rates. FDI, unlike FPI, money market instruments etc. cannot not be traded on markets and are relatively very illiquid forms of assets. Thus, any anticipated changes in 'e' rates, or such volatility in the relatively short-run, should not affect FDI decisions, as much as the economic state of the recipient nation should.

Analysis is between Canada and the US, using Canada as country under analysis.

Data - International Global Affairs of Canada, Government of Canada Database.

We have further sub-categorized Financial flows into: 
International Journal of Social Science and Economic Research

ISSN: 2455-8834

Volume:05, Issue:08 "August 2020"

\subsubsection{Net acquisition of financial assets -}

\section{A) Canadian portfolio Investments(stocks and money market instruments):}

Correlation $=-0.2135$ (Weak). As we can see in the graph below, the movement of investment numbers is incredibly volatile and is not following a particular or specific trend with 'e' rates.

\section{Canadian portfolio investment}
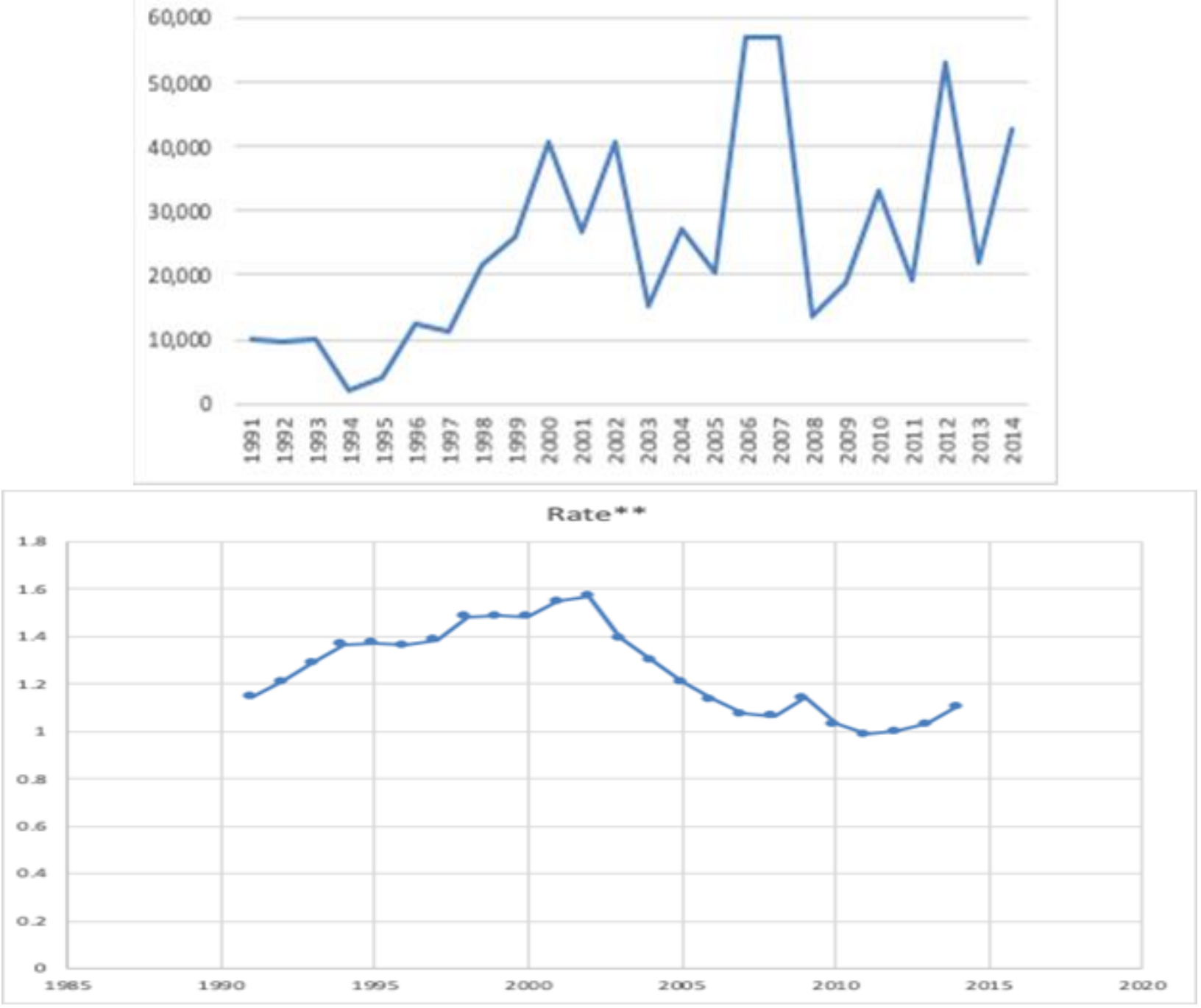


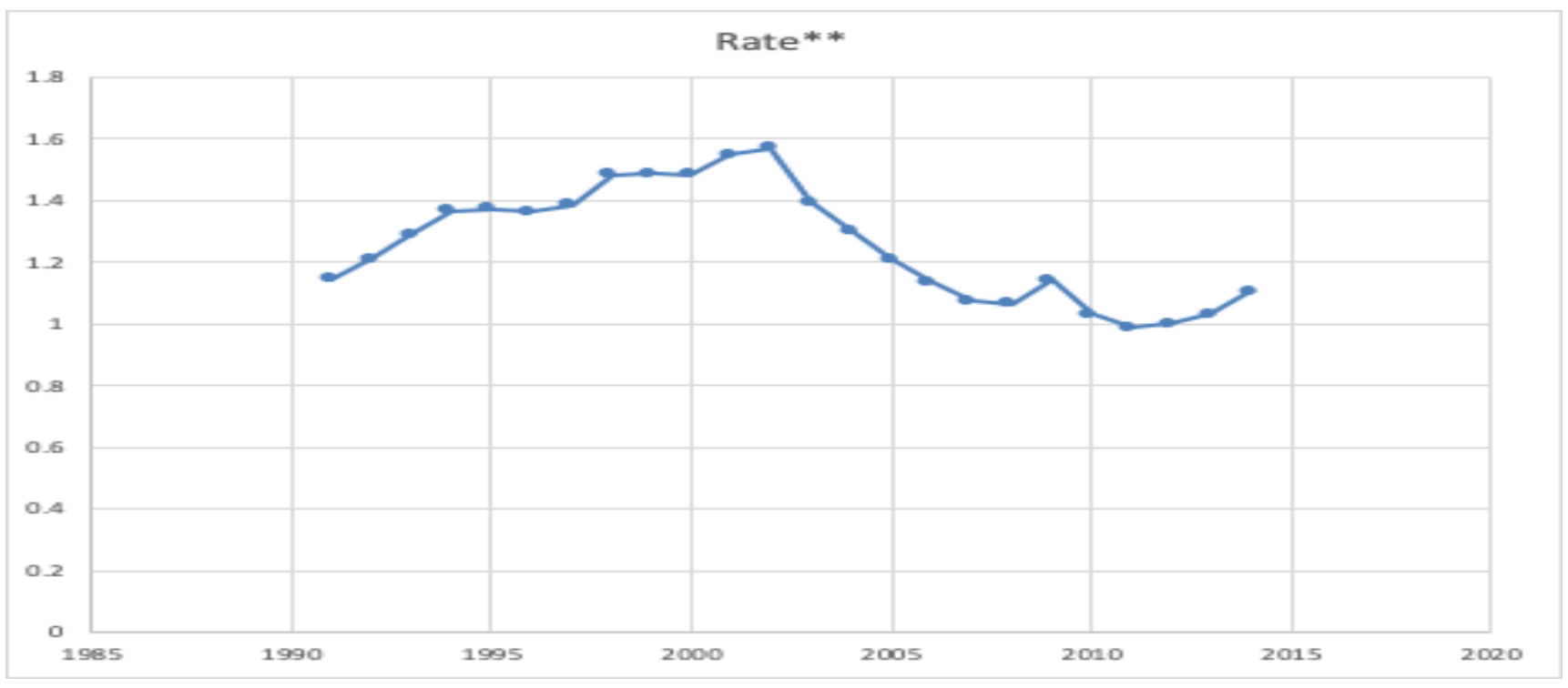

Till 2001, 'e' rose consistently and to a certain extent so did Canadian Portfolio Investment. This could be rationalized as since 'e' rates were consistently rising in, Canadians expecting the same in future, would continuously invest more abroad (US), so that when they receive returns in foreign currency units, they get higher returns on account of depreciating currency. This process is also at times referred to as destabilizing speculation.

Furthermore, 9/11 attacks created panic in the market and resulted in Canadian withdrawal of Investment from the US. Thus, a dip is seen around 2001.

Post 2000, a broader negative relation does emerge. This can rationalize using the stabilizing speculation principles; as ' $\mathrm{e}$ ' is falling, one would expect the same to rise in the future, thus increasing expected foreign currency investment returns.

A stark volatile period is during 2005 - 2009; prior to the GFC, investment in the USA shot to record height, simply because of housing market profitable frenzy that existed. To reap maximum profits investors from across the globe poured money into the US financial sector. However as soon as crisis struck in 2008, these investments dropped considerable, as is evident in the graph above.

\section{B) Other Canadian investment}

This consists of loans, deposits and reserves in the USA. 
International Journal of Social Science and Economic Research

ISSN: 2455-8834

Volume:05, Issue:08 "August 2020"

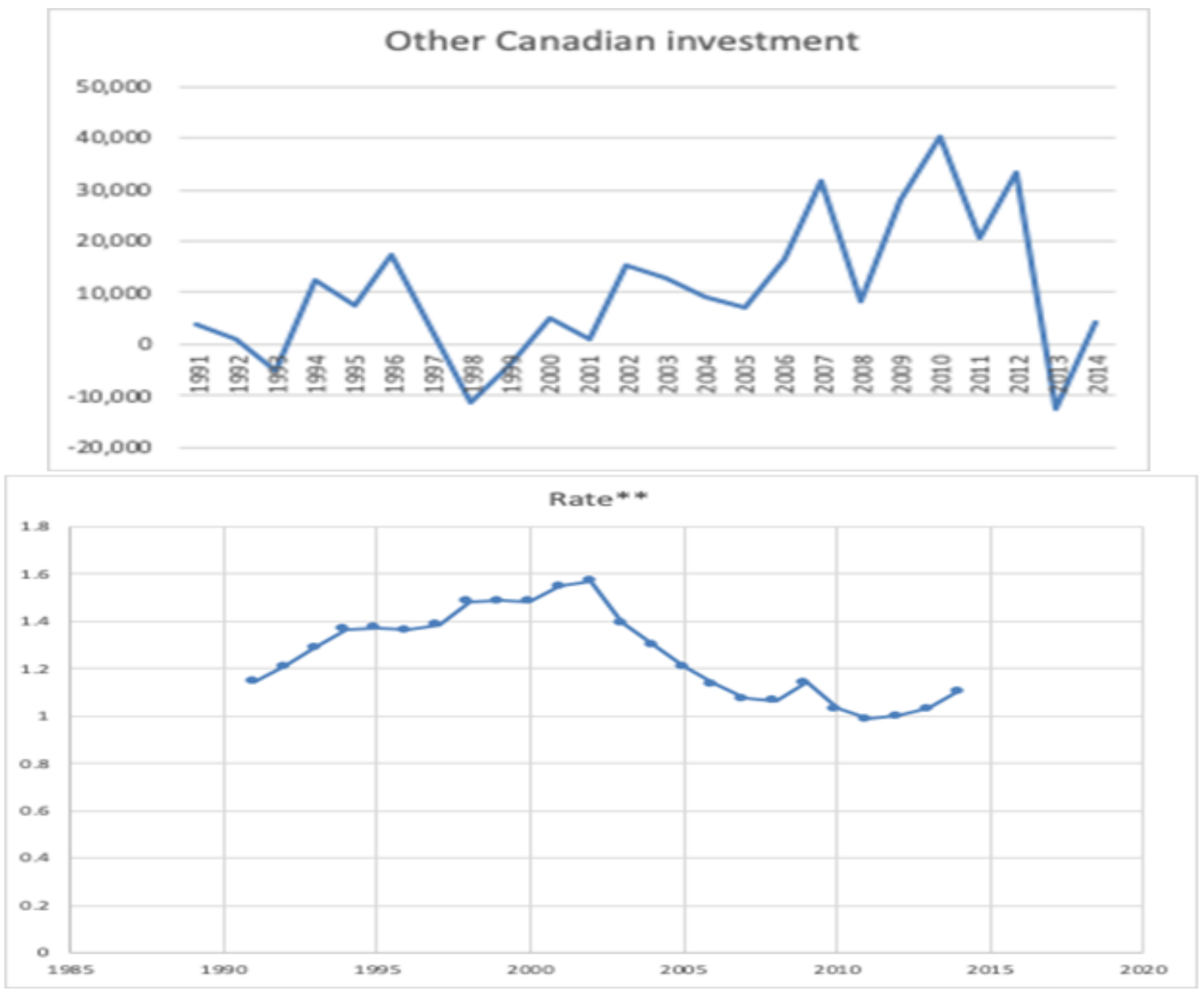

Correlation $=-0.44$ which is weak. The trend pattern $\&$ analysis remains broadly the same as that of the previous section.

\subsubsection{Net incurrence of liabilities -}

C) Foreign portfolio investment (stocks and money market instruments) 
International Journal of Social Science and Economic Research

\section{Foreign portfolio investment}
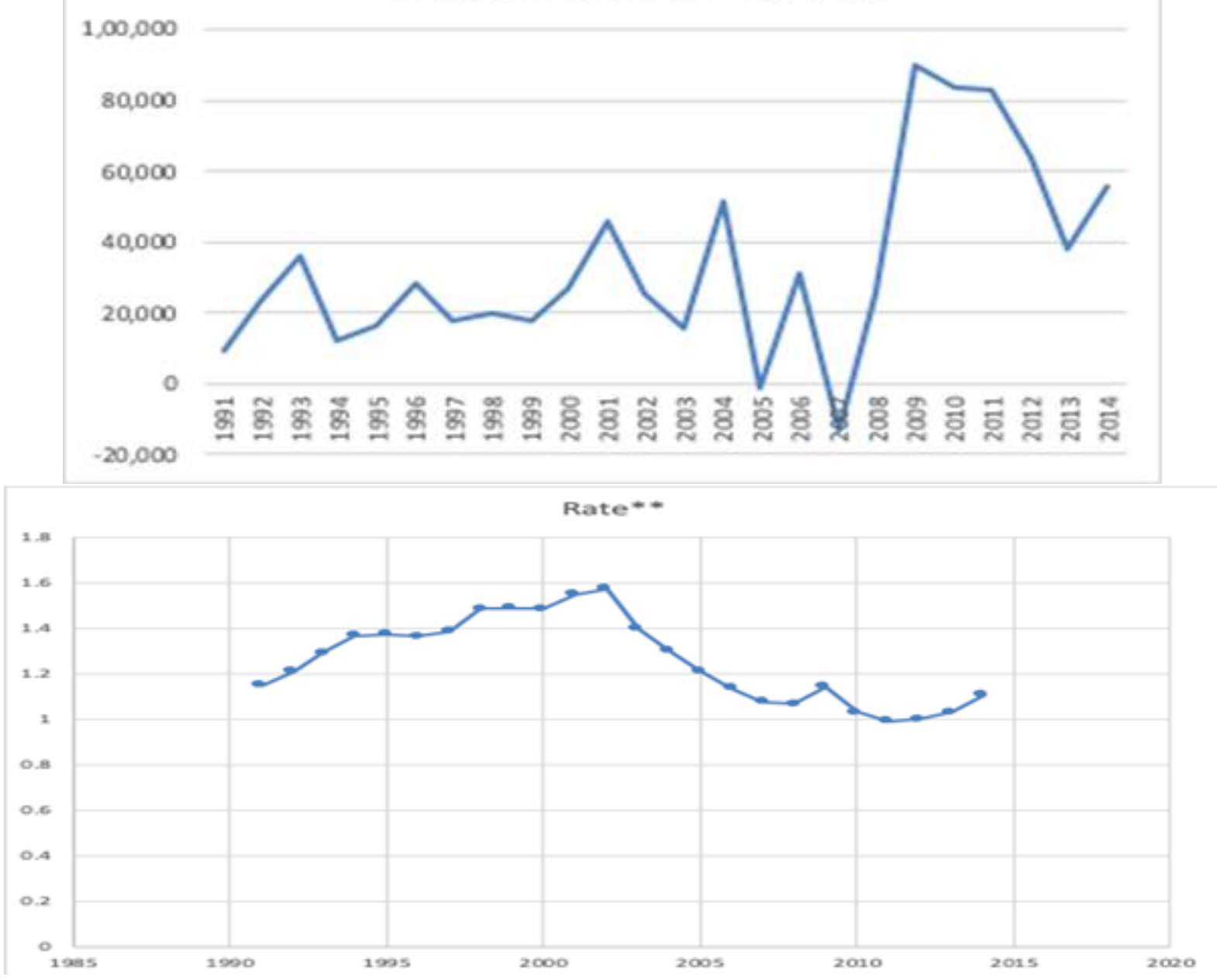

The trends can be explained by simply reversing and rationalizing the aforementioned arguments from the US investor perspective.

\subsection{Testing the CIAP:}

According to the CIAP, arbitrage opportunities should be absent and the equation below should be observed:

$$
\begin{aligned}
& \mathrm{i}-\mathrm{i}^{*}=\left(E_{\mathrm{CAD}} / \mathrm{US} \$, t+1-E_{\mathrm{CAD}} / \mathrm{US} \$, t\right) / E_{\mathrm{CAD}} / \mathrm{US} \$, t \\
& \text {; where } i=\text { Canada interest rates } \\
& i^{*}=\text { USA Interest Rates }
\end{aligned}
$$


International Journal of Social Science and Economic Research

ISSN: 2455-8834

Volume:05, Issue:08 "August 2020"

We make use of 3-month forward CAD\$/US\$ 'e' rates and 3-month US T-Bills and 3-month Canadian sovereign bills. Time period - 2009-2019.

We use daily traded rates.

(Data was extracted from MecklaiFinancial, US FRED-St. Louis FED Database, Bank of Canada)

We use T-Bills as a proxy for ' $\mathrm{i}$ ' rates in general, because especially in US and Canada these securities are marketed completely and are also the bulk of such financial activities, hence reflecting true costs of credit (Balke, Wohar, 1997).

As seen below, the points do form a pattern which resembles a diagonal line crossing the origin, however it is sloped less than a 45-degree line. Quite a few points fall within the dotted blue line (which accounts for transactions costs, approximated to $0.125 \%$ as per a study conducted by Frenkel and Lavish (1981)).

The red dotted line accounts for almost every other point, and as is evident shows that arbitrage opportunities for around $0.5 \%$ exist, which are negligible. Furthermore, such deviations from CIAP are often considered a consequence of capital market imperfections such as capital controls and/or political risk (Prachowny, 1970; Frenkel, 1973; Dooley and Isard, 1980; Otani and Tiwari, 1981; and Blenman 1991),imperfect substitutes and political risk (Aliber, 1973), as well as tax differentials and inelastic demand and supply. 


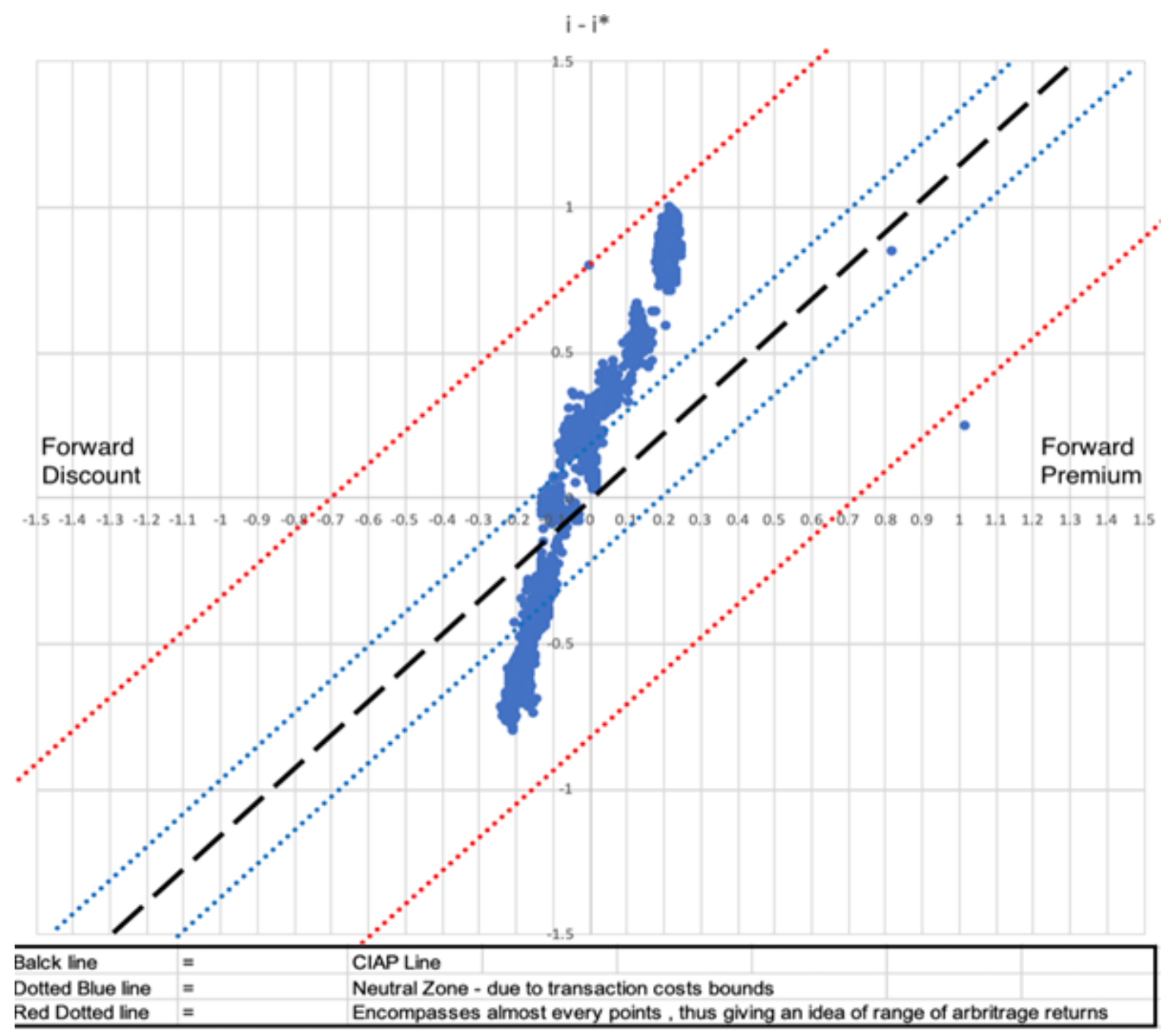

A limitation of this test is that we have used only T-Bill rates as a proxy for ' $i$ ', whereas ' $e$ ' rates are influenced by every sort of interest rate in the market.

\section{Limitations:}

1) 'e' rates result in and reflect financial flows with the entire world and thus singling out the same between one country may not yield perfect results.

2) The link between 'e' rates and financial flows is not largely in one direction with both affecting the other. This endogeneity is too significant to establish any one-way movement or directions of the variables.

3) Most data values used do not reflect daily fluctuations. 


\section{International Journal of Social Science and Economic Research}

ISSN: $2455-8834$

Volume:05, Issue:08 "August 2020"

\section{Conclusion}

We notice that when individually taken as determinants of exchange rate, the two factors interest rate and inflation have a very weak relation and the models suffer from a very poor fit. When we however take a multivariate regression model accounting for two additional factors, then our model fits incredibly well and the factors show expected relations in terms of their coefficients.

We then go on to calculate the relative weights of each of these factors in the entire model, and notice that relative factor productivity can have a surprisingly great effect on the ' $\mathrm{e}$ ' rates. A major reason for the same could be the fact that factor productivity moulds expectations which can often turn into reality; in other words, expectations tend to fulfill themselves. Furthermore, we notice that ' $\mathrm{e}$ ' rates depend to a great extent on investor expectations and thus the general investor perception of the Canadian economy; along with which relative interest rates serve as major motivations. Relative inflations on the other hand seems to have a diminutive impact on 'e' rate changes, perhaps because inflation is largely a domestic phenomenon, however this result does seem contradictory to the existing aphorism with regards to the relation between inflation and 'e' rates.

On analyzing the trend of capital flows with exchange rate we notice a dichotomous relation in two sub-periods, one where 'e' rates rise and capital flows fall and vice-versa; the rational for the same could be differences in direction of causality as well as the J-curve effect.

Our final analysis on the CIAP shows results largely in tandem with the existing literature on the same. After accounting for the transaction cost factors, we observe $0.5 \%$ arbitrage opportunities available, however such negligible rates of return are often rationalized as a consequence of capital market imperfections.

\section{Future Scope}

Scope for future study exists in trying to account for multiple other factors along-with those already mentioned as determinants of the exchange rate movements. Furthermore, a detailed time series regression analysis is required to study better the impact of exchange rate movements on cross country capital flows.

For the entire analysis we take the USA as our supporting country assuming that domestic changes in US macroeconomic factors will likely have the greatest impact on Canadian exchange rate. However, an attempt should be made to account for other countries which Canada has significant trade and capital flows with. 
International Journal of Social Science and Economic Research

ISSN: 2455-8834

Volume:05, Issue:08 "August 2020"

For the CIAP analysis we use 3-month T-bill rates as the best measure for interest rates. However, attempts should be made to account for the interest rates on several other financial instruments so as to enhance accuracy of our findings.

The Neo-Fisherism test done in the appendix requires a more in-depth analysis than the one currently done. A regression analysis accompanied with structural break tests like the Chow test in and around the 2008 financial crisis period could hold key to more refined and precise findings.

\section{REFERENCES}

\section{Literature Review:}

Alper, F. O. (2014). Impact of Exchange Rate Volitality On Trade: A Literature Survey.

Bailliu, J., \& King, M. R. (2005). What Drives Movements in Exchange Rates?

Balke, N. S., \&Wohar, M. E. (1997). Nonlinear Dynamics and Covered Interest Parity. Working Paper (Fedral Reserve Bank of Dallas).

Floyd, R. (2016). Econometric modeling of exchange rates determinants of market classification: An empirical analysis of Japan and South Korea using sticky price monetary theory.

Fong, F. (n.d.). Determinants of the Canada- US Exchange Rates: from Commodities to Current Account.

Grauwe, P. D. (1988). Exchange Rate Variability and Slowdown in Growth of International Trade .Staff Paper (IMF), 63-84.

Levich, R. M. (2017). A Brief Survey of Measuring and Exploiting Deviations from Covered Intrest Parity.

Li, R. M. (2013). The Impact of Subprime Financial Crisis On Canada on United States Housing Market and economy.

\section{Data Sources:}

(n.d.). Retrieved from FRED, St. louis: https://fred.stlouisfed.org

(n.d.). Retrieved from CEIC: https://www.ceicdata.com/en

(n.d.). Retrieved from data.gov: https://www.data.gov 


\section{International Journal of Social Science and Economic Research}

ISSN: $2455-8834$

Volume:05, Issue:08 "August 2020"

(n.d.). Retrieved from bank of canada: https://www.bankofcanada.ca

(n.d.). Retrieved from Federal reserve board- data: https://www.federalreserve.gov/data.htm

Bank of Canada. (2012). The Exchange Rate.

Business confidence index. (2018). Retrieved from oecd.org: https://data.oecd.org/leadind/business-confidence-index-bci.htm

Canada imports from United States. (2019, October 11). Retrieved from WITS: https://wits.worldbank.org/CountryProfile/en/Country/CAN/StartYear/1989/EndYear/ 2017/TradeFlow/Import/Partner/USA/Indicator/MPRT-TRD-VL

Data for Canada, United States . (2019). Retrieved from the world bank: https://data.worldbank.org/?locations=CA-US

Global Affairs Canada. (2014, 05 29). Canada and United States capital and financial account - Retrieved from https://www.international.gc.ca/economist-economiste/statisticsstatistiques/data-payments-paiments/data-BOP_capital-fin/BP_Canada_US-

EU_Capital.aspx?lang=eng

Historical data forward rates. (2016). Retrieved from Mecklai Financial: http://www.mecklai.com/Digital/MecklaiData/HistoryData_Forward

Perspectives . (2019, October 07). Retrieved from CNN Business: Trump's new trade deal with Canada and Mexico ... - CNN.comhttps://www.cnn.com > 2019/10/07 > perspectives > usmca-trade-deal-mexic...

\section{Articles and Stories:}

(Express, 2019)

https://www.americanexpress.com/us/foreign-exchange/articles/international-tradeunited-states-canada/

(Trade, 2019)

https://www.google.com/url?sa=t\&rct=j\&q=\&esrc=s\&source=web\&cd

(Express A. , 2019)

https://www.google.com/url?sa=t\&rct=j\&q=\&esrc=s\&source=web\&cd=17\&cad

(Canada, n.d.)

https://www.google.com/url?sa=t\&rct=j\&q=\&esrc=s\&source=web\&cd=20\&cad

(CNN, 2019)

https://www.google.com/url?sa=t\&rct=j\&q=\&esrc=s\&source=web\&cd=22\&cad= (Daily, n.d.)

https://www.google.com/url?sa=t\&rct=j\&q=\&esrc=s\&source=web\&cd=23\&cad=rja (ranalytics, n.d.) 
International Journal of Social Science and Economic Research

ISSN: 2455-8834

Volume:05, Issue:08 "August 2020"

https://www.google.com/url?sa=t\&rct=j\&q=\&esrc=s\&source=web\&cd=19\&cad

(Moody's, n.d.)

https://www.google.com/url2FUnited-States-Treasury-International-Capital-

Flows\&usg=AOvVaw1-4FsTRrQnyPCgMm_CbZG_

(Mail, 2019)

https://www.google.com/url?saFarticle-why-canada-saw-a-60-increase-in-foreign-

direct-investment-last-year\%2F\&usg=AOvVaw37bzSuU91Y-8mwb2pyTXf8

\section{Appendix}

\section{NAFTA and the Global Financial Crisis (GFC):}

The broad timeline we have considered is 1990 - 2018, so as to include formation of NAFTA and the Global Financial Crisis, both of which have had significant impacts on the way the variables under study behave.

NAFTA, was a free trade agreement signed between Canada, USA and Mexico (implemented in 1994) which integrated further, an already relatively integrated economy.

A primary motive for NAFTA to come into effect was to reduce the trade deficit of the US. However, this clearly did not happen, since the trade deficit widened. A graph is shown later in the analytical section.

The infamous GFC had devastating effects on both the nations, and was a blow to America's image as a stable and secure economy. Since Canada and US are both closely integrated economies, both in terms of trade and finance (so much so that their housing markets also move in tandem) a blow in US led to the same in Canada. Thus, a fall in trade.

The 9/11 attacks raised restrictions by US due to stricter regulations, and Canada was subject to the same. As a consequence, Canadian exports suffered.

We have studied these in context of trade and capital flows.

\section{Effect of Relative Factor Productivity and Political and Economic State on 'e' rates:}

\subsection{Factor Productivity:}

According to the bank of Canada a rise in productivity would strengthen a currency, however a regression run (time - 1980 - 2018) between indexed relative multi factor productivity and 'e' rates displays contrary results i.e. a positive relation instead of a negative one):

(The indicator used is that of multi-factor productivity, obtained from OECD) 
Multi-factor Productivity (MFP) reflects the overall efficiency with which labour and capital are used together in the production process. Changes in MFP reflect the effects of changes in management practices, brand names, organisational change, general knowledge, network effects, spillovers from production factors $\mathrm{m}$ adjustment costs, economies of scale, the effects of imperfect competition and measurement errors. Growth in MFP is measured as a residual , i.e. that part of GDP growth that cannot be explained by changes in labour and capital inputs.

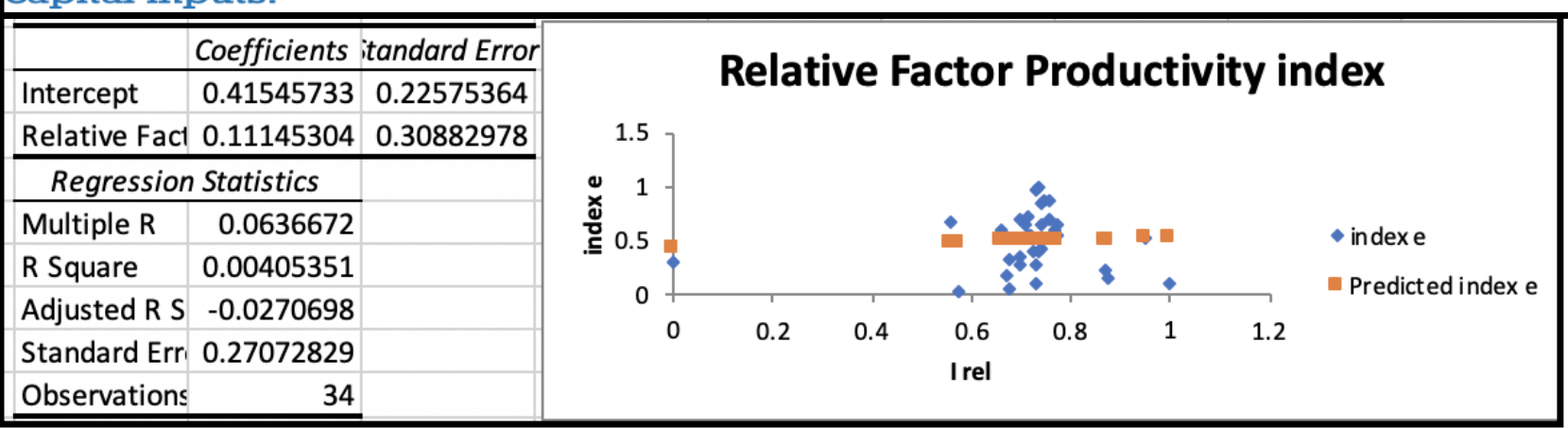

The above findings can be rationalized on the basis that rising productivity finds its way to ' $\mathrm{e}$ ' rates, by affecting incomes which in turn perhaps raise domestic inflation in addition to a tendency to import, both of which raise ' $e$ ' that is depreciate the currency.

\subsection{The political and economic state:}

The better these conditions, the stronger a currency is likely to be, given that greater confidence in an economy would increase capital flows and currency holdings; both of which appreciate a currency. Toanalyze the effect of the same we use the 'Ease of Doing Business Index' (time :2006-2018; OECD data).

Running a regression presents results we expect (a negative relation between the two) :

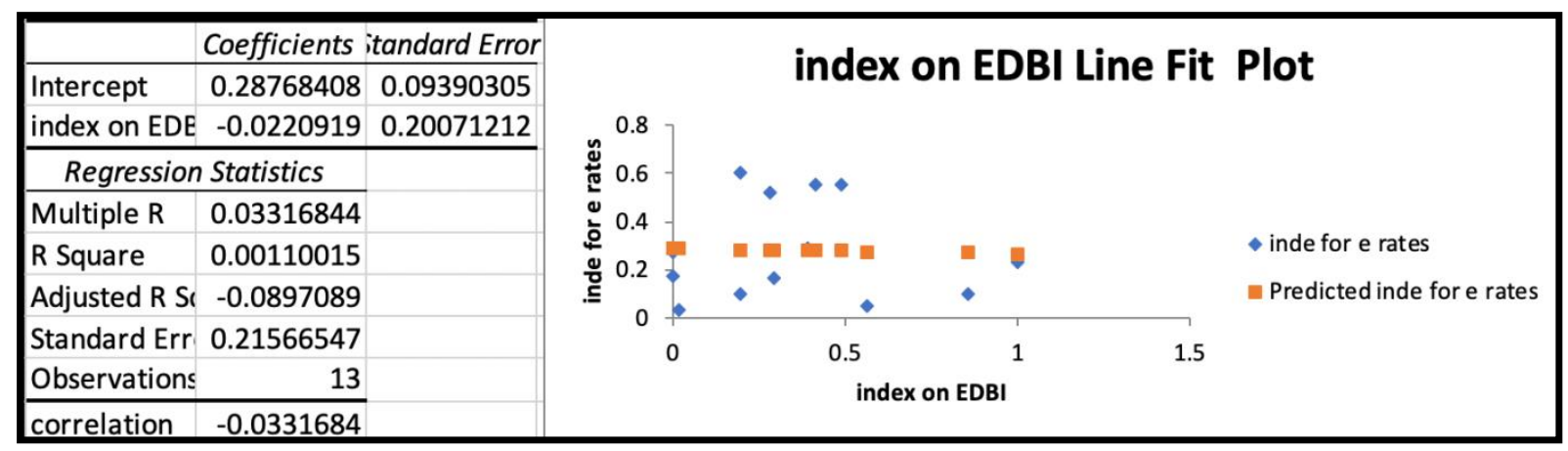

However, as we can see above ( 0.0011 regression coef. \& -0.033 correlation) the relation is almost non-existent. 


\section{International Journal of Social Science and Economic Research}

ISSN: 2455-8834

Volume:05, Issue:08 "August 2020"

\subsection{NEO-FISHERISM:}

Fisher's equation relating nominal interest rates to expected inflation is known all over. In fact if we take expected inflation I'e' to be the current inflation (efficient markets hypothesis), an increase in inflation would lead to a rise in nominal interest rates ' $i$ ', since real interest rates ' $R$ ' tend to remain stable (stable does not mean constant, it simply implies that ' $R$ ' would be determined by global demand and supply conditions which would stable since ' $R$ ' would be a long-run stable equilibrium.

The equation is: $\mathrm{i}=\mathrm{R}+\mathrm{I}^{\mathrm{e}} \textrm{ }$

Approximating I'e' to I (present) and assuming ' $\mathrm{R}$ ' to attain long-run equilibrium in the long run : Any change in inflation would lead to a direct proportionate change in nominal interest rates.

Thus, Fisher saw the causal link moving from inflation to nominal interest rates. However, Neo Fisherists see the causal link in a reverse way. Again, considering the same assumptions, they believe a change in ' $i$ ' will cause a directly proportional change in inflation. Thus, they believe that considering full-flexibility of markets (in the long run), the conventional monetary policy would create an opposite effect.

To test the validity of the same we run regressions between ' $i$ ' and 'I' (once with ' $i$ ' as dependent and once with 'I' as dependent variable) for the USA (time period - 1990-2018). Variables used are indexed.

According to conventional monetary policy, interest rates and inflation numbers should have a negative relation;thus, a negative correlation and regression coefficient.

Since we are testing this equation in relation to it being a monetary policy tool, we consider ' $i$ ' to be US monetary Policy Rates.

\section{Results of the regressions are given below:}

A) 'Fisher' Regression ('i' as the dependent variable)

B) 'Neo-Fisher' Regression ('I' as the dependent variable): 
International Journal of Social Science and Economic Research

ISSN: 2455-8834

Volume:05, Issue:08 "August 2020"

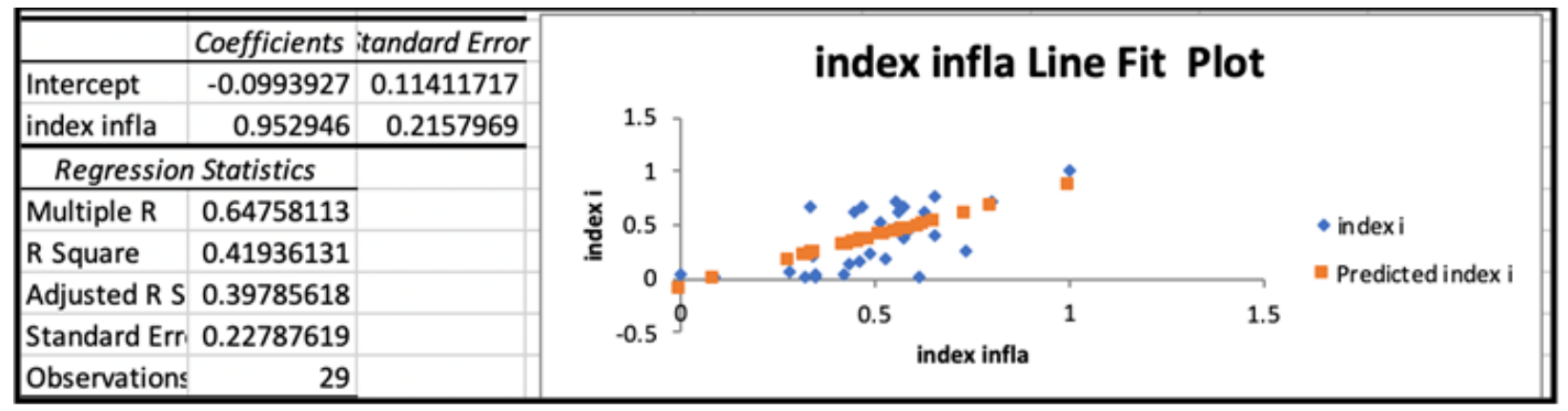

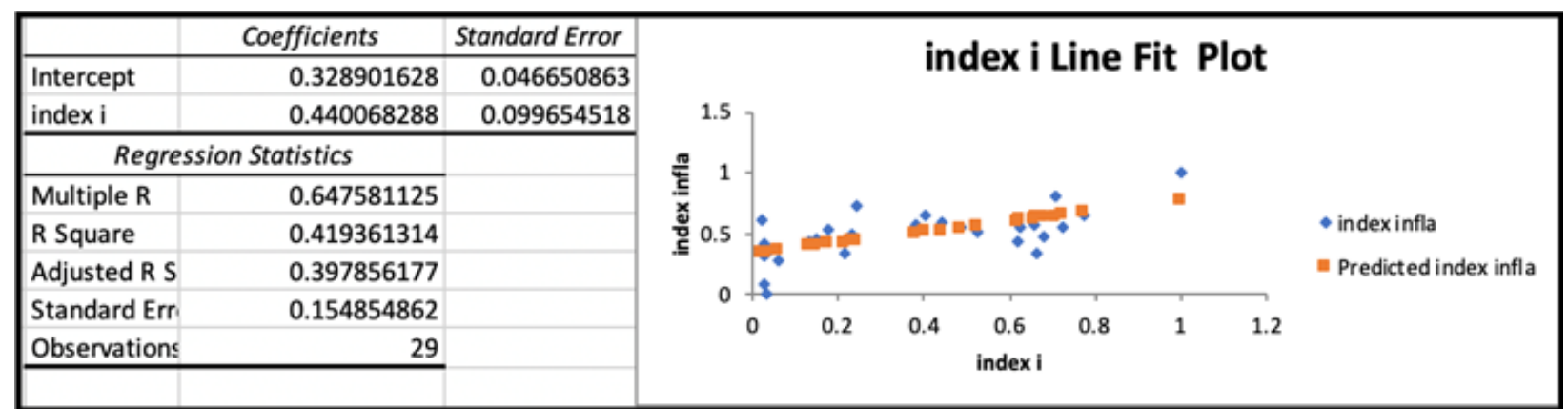

As is evident from the results above, the relation between ' $i$ ' and ' $I$ ' is clearly positive, hence conventional monetary policy seems disadvantaged. Regardless of which regression we take, an increase in either will lead to an increase on the other.

To now check which hold better,Fisherism or Neo-Fisherism we will need to run a causality test. Given limitations, the causality test is not conducted, however we simply look at the standard error values to get an idea of as to which regression has a better fit of data.

The lower standard error in Neo-Fisherism indicates that the 'Neo-Fisher' regression has a better fit.

In the absence of a causality test, confirming which is prevalent is not sensible. However,the positive relation between the two variables, with certainty places the conventional monetary ideology at a disadvantage. 


\section{International Journal of Social Science and Economic Research}

ISSN: 2455-8834

Volume:05, Issue:08 "August 2020"

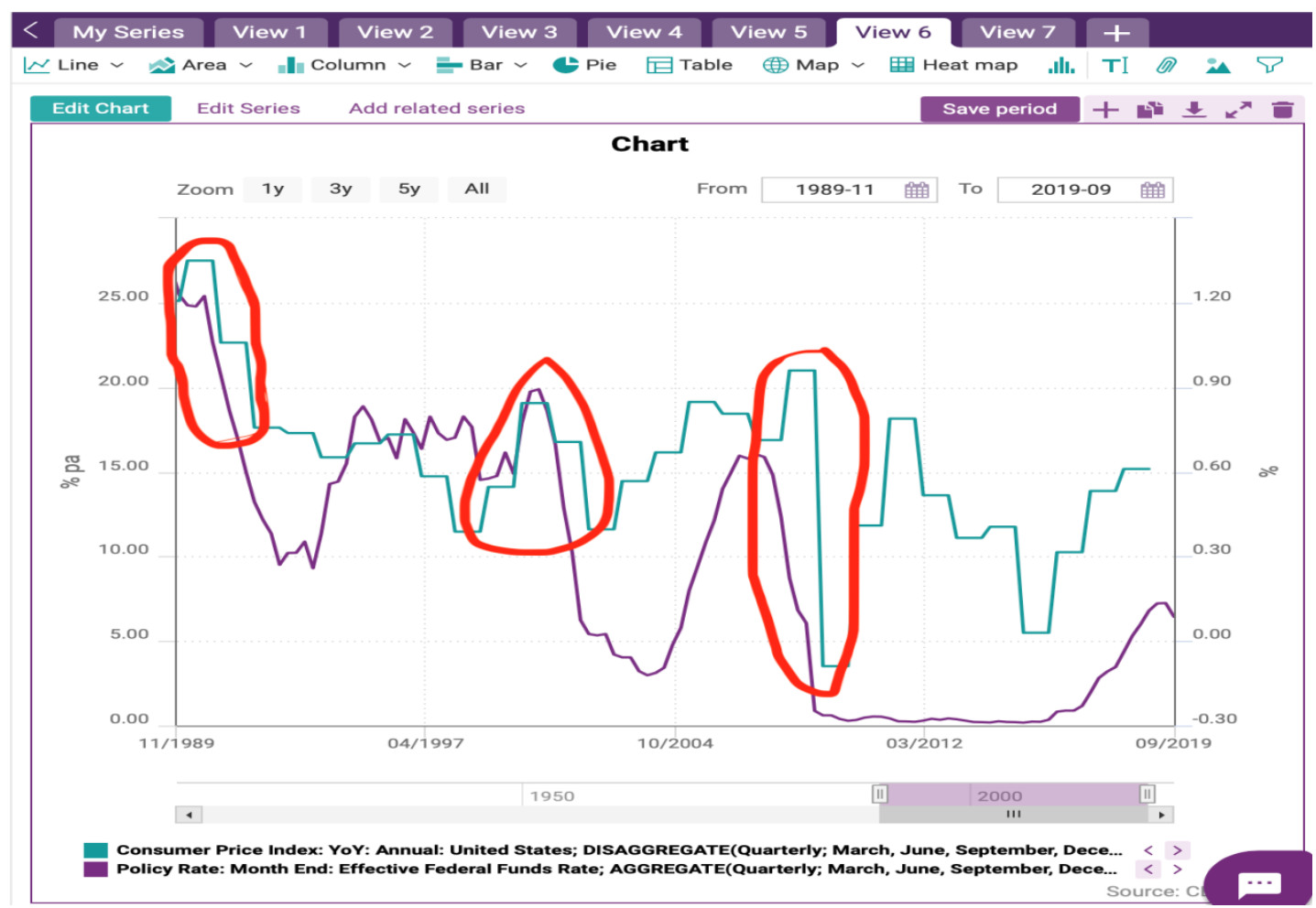

\{Moreover a regression done between non-indexed values yielded a reg.coeff of 0.007 which is an indication of the absence of the law of Purchasing Power Parity in the short run; in case PPP were to hold the regression coefficient should have been one so as to indicate a one to one transfer between the two variables; keep in mind the relation :

Nominal 'e' rate $=$. Real 'e' rate $*$ (price level domestic / price level foreign)

[If PPP holds Real 'e' rate $=1$ ] 